Kematian, Monumen Kubur, Dan Pelapisan Sosial Masyarakat Di Sumba Timur

\title{
Diman Suryanto
}

Keywords: burials, megalithic, social strata, symbol, ornament, decorative patterns

\section{How to Cite:}

Suryanto, D. (2003). Kematian, Monumen Kubur, Dan Pelapisan Sosial Masyarakat Di Sumba Timur. Berkala Arkeologi, 23(1), 42-52. https://doi.org/10.30883/jba.v23i1.859

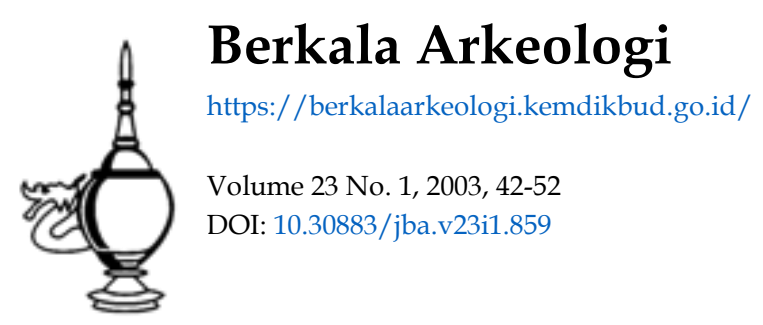

\section{c) (7)(2)}

This work is licensed under a Creative Commons Attribution-NonCommercial-ShareAlike $\underline{4.0 \text { International License. }}$ 


\section{KEMATIAN, MONUMEN KUBUR, DAN PELAPISAN SOSIAL MASYARAKAT DI SUMBA TIMUR}

\section{Diman Suryanto}

\section{$\mathbf{P}$}

\section{endahuluan}

Daerah Sumba Timur yang terdiri dataran rendah maupun pegunungan memiliki potensi yang besar dalam bidang kepurbakalaan. Dewasa ini peranan daerah Sumba Timur meningkat dan lebih banyak menarik perhatian para peneliti, baik peneliti arkeologi, antropologi dan disiplin ilmu lainnya (Kapita, 1976).

Berbagai bentuk tinggalan arkeologi dalam wujud monumen-monumen, serta adanya tradisi-tradisi yang mencerminkan adanya kebudayaan megalitik, tersebar secara menyeluruh dan hampir ditemukan di setiap kampung. Jenis tinggalan arkeologi yang monumental, secara garis besar dapat dibedakan menjadi (1) reti atau kubur dolmen, (2) kabang atau peti batu, (3) benteng atau pagar batu, (4) Katoda atau tiang pemujaan dan (5) penji atau batu tegak (menhir) (Ayu Kusumawati, 1984)

Selain bentuk-bentuk kubur ini, terdapat juga peninggalan dalam bentuk kubur tempayan di desa Melolo, Kecamatan Rindiumalulu; dan di desa Kawangu, Kecamatan Pandawai, Kabupaten Sumba Timur. Tentang kubur tempayan di Melolo telah ditulis dalam sebuah buku oleh Van Heekeren (1956). Rupanya bentuk kubur (monumen kubur) dan kubur tempayan di Sumba Timur ini, adalah merupakan bentuk umum dari tinggalan megalitik dfi Indonesia, seperti apa yang telah diklasifikasikan oleh Van der Hoop dalam bukunya Megalithic Remain in South Sumatra (1932). Kemudian Haris Sukendar, membuat klasifikasi temuan megalitik di Indonesia menjadi 3 (tiga) kelompok, yaitu : (1) tempat pemujaan, (2) tempat penguburan dan (3) tempat pemukiman

Pulau Sumba merupakan salah satu pulau di wilayah Propinsi Nusa Tenggara Timur, berada pada $10^{\circ}$ Lintang Selatan dan $120^{\circ}$ Bujur Timur. Secara administrasi Pulau Sumba dibagi menjadi dua kabupaten yaitu Kabupaten Sumba Barat dan Kabupaten Sumba Timur. Sumba Barat beribukota Waikabubak, sedang Sumba Timur beribukota Waingapu. Uraian selanjutnya dalam makalah ini akan difokuskan pada daerah Sumba Timur. Kabupaten Sumba Timur terdiri dari enam kecamatan, yaitu (1) kecamatan Pandawai, (2) kecamatan Rindiumalulu, (3) kecamatan Palungalodu, (4) kecamatan Paberiwai, (5) kecamatan Tabundung, dan (6) kecamatan Lewa.

Secara geografis keadaan tanahnya berbukit-bukit, terutama di daerah pedalaman. Keadaan alam yang demikian, menyebabkan daerah-daerah pedalaman hanya dapat dicapai dengan sarana transportasi kuda. Daerah-daerah itu adalah kecamatan 
Palungalodu, Paberiwai dan Tabundung. Sebagian daerah-daerah pedalaman tersebut, ditumbuhi padang rumput menyebabkan sebagian besar penduduk Sumba, mengusahakan peternakan. Binatang ternaknya terdiri dari kuda, sapi dan babi. Di samping beternak sebagian penduduknya juga beraktivitas pertanian, terutama penduduk di kecamatan Lewa. Suatu penghasilan tambahan yang merupakan industri rumah tangga adalah kerajinan menenun. Kerajinan ini dilakukan oleh seluruh masyarakat, baik golongan bangsawan (maramba), maupun rakyat biasa. Kain Sumba khususnya buatan Sumba timur, terkenal karena nilai keindahannya.

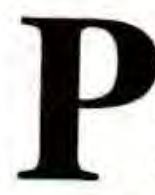
elapisan Sosial Masyarakat

Dalam masyarakat Sumba Timur ada sistem pelapisan sosial. Pelapisan ini didasarkan atas kelahiran, turunan dan derajat. Adapun pelapisan itu terdiri atas empat pelapisan sosial, yaitu (1) ratu atau iman (masyarakat yang pengatur kebaktian), (2) maramba atau ningrat (pengatur masyarakat) dan (3) kabihu, yaitu orang merdeka, dan (4) ala atau hamba sahaya Golongan pertama dan kedua kerapkali disatukan dalam sebutan ratu-maramba (Kapita, 1976).

Lapisan maramba, adalah golongan ningrat (bangsawan) yang berusaha mempertahankan derajatnya. Golongan maramba dibedakan menjadi dua, yaitu maramba bokulu (ningrat besar) dan maramba kudu (ningrat kecil). Penggolongan ini antara lain didasarkan atas kemurnian darah. Golongan maramba ini mempergunakan gelar rumbu untuk bangsawan pria dan rambu untuk bangsawan putri.

Lapisan kabihu, adalah golongan yang merdeka atau golongan yang mempertahankan nama sukunya (kabihunya). Golongan ini dibedakan mejadi dua, yaitu kabihu bokulu (besar) dan kabihu kudu (kecil). Dari golongan kabihu bokulu inilah muncul golongan pahlawan yang menjadi pelopor dalam peperangan bila diserang atau menyerang
musuh.

Lapisan Ata, adalah golongan hamba. Golongan ini sering pula disebut dengan istilah angupiti, artinya pembantu atau penolong. Ata ini dibedakan menjadi Ata ndai (hamba pusaka) dan Ata bidi (hamba baru). Ata ndai adalah golongan hamba yang turun temurun tinggal bersama-sam dengan tuannya. Dari golongan ini kemudian merupakan orang-orang yang terpercaya dan diberi jabatan tertentu, misalnya hulubalang pembicara. Sedang golongan Atandai merupakan tawanan perang, yang diperjual belikan. Pada masa sekarang golongan ini sudah tidak ada lagi. 
Masyarakat Sumba Timur yang mengenal pelapisan sosial seperti tersebut di atas, di samping itu mempunyai kepercayaan asli yang disebut marapu. Kepercayaan asli ini ternyata kuat bertahan sampai sekarang, meskipun agama Kristen, Katolik dan Islam telah berkembang dan dianut oleh masyarakat dengan pesat. Hal tersebut dibuktikan dengan adanya suatu kenyataan, bahwa di antara penduduk yang secara resmi telah menganut agama Kristen atau agama lain, masib belum melepaskan adat istiadat serta konsep-konsep kepercayaan marapu. Suatu unsur penting dalam kepercayaan ini adalah adanya keyakinan, bahwa roh merupakan komponen yang utama. Atas dasar keyakinan ini, maka roh leluhur dimuliakan sebagai marapu, yang hidup di negeri marapu (Pantai Marapu). Kehidupan di Pantai Marapu merupakan kehidupan abadi, sehingga kedudukan roh leluhur akan sama seperti ketika ia masih hidup di dunia (B. Soelarto, $\mathrm{tt}$ ).

Dengan adanya konsep-konsep tersebut di atas maka dalam kehidupan masyarakat Sumba Timur, berlaku upacara-upacara yang bertujuan untuk pemujaan roh nenek moyang. Upacara itu pada umumnya dengan uborampe yang merupakan saji-sajian antara lain berupa sirih pinang dan binatang korban. Kebiasaan mengadakan upacara korban menyebabkan usaha peternakan mempunyai dua tujuan, yaitu untuk memenuhi kebutuhan sehari-hari dan sebagai persediaan untuk upacara korban. Upacara pemujaan dilakukan pada peristiwa-peristiwa yang berkaitan dengan bercocok tanam, perkawinan, pembuatan rumah adat dan kematian.

Sebagai sarana untuk mengadakan kontak dengan marapu (baca nenek moyang), maka dibuatkan rumah adat yang khusus digunakan sebagai tempat upacara. Pembuatan rumah adat ini disertai dengan binatang korban yang terbaik. Para ratu menjalani pantangan tertentu, agar pembangunan rumah adat berjalan lancar. Selain rumah adat, dididrikan pula sebatang kayu katoda (tiang pemujaan) yang berfungsi sebagai tempat turunnya marapu bila upacara diadakan. Katoda-katoda diadakan dan didirikan di tempat-tempat tertentu, misalnya di ladang, di muara sungai, di batas desa atau di depan rumah adat.

Melalui upacara-upacara tersebut diharapkan marapu memberi kesuburan, keseimbangan dan keselamatan. Atas dasar ini maka pelaksanaan upacara dilakukan secermat-cermatnya, karena kesalahan dalam pelaksanaan upacara akan mengakibatkan malapetaka.

\section{$\mathbf{K}$}

\section{Tematian di Sumba Timur}

Saat kematian bagi masyarakat Sumba pada umumnya dan masyarakat Sumba Timur pada khususnya merupakan masa yang penting, karena saat itu merupakan saat perpindahan roh dari alam fana ke alam baka. Di alam baka seperti 
halnya di alam fana roh memerlukan kebutuhan hidup, misalnya makanan dan pakaian. Anggapan seperti tersebur di atas, menyebabkan saat kematian selalu diikuti dengan upacara-upacara. Bahkan upacara kematian merupakan upacara yang paling menyolok dalam kehidupan masyarakat Sumba Timur. Besar kecilnya upacara tersebut disesuaikan dengan kedudukan si mati, serta sebab kematiannya.

Masyarakat Sumba Timur mengenal dua macam kematian yaitu, (1) kematian panas (mati mbana) dan (2) kematian dingin (mati maringu). Kematian panas adalah kematian yang luar biasa artinya suatu kematian yang tidak disebabkan karena suatu penyakit, tetapi disebabkan oleh hal-hal yang darurat misalnya kecelakaan, terbunuh, bunuh diri, atau mati dalam peperangan. Orang yang mati karena kalah perang atau bunuh diri harus segera dikuburkan di luar kampung. Sedang orang yang mati terbunuh sebagai akibat karena kejahatan, misalnya merampok, membunuh, akan dikubur tanpa upacara. Di atas kuburan orang mati malang ini, ditimbuni onak dan duri (Kapita, 1976).

Bagi kematian dingin yaitu kematian yang disebabkan karena penyakit, diikuti dengan upacara tertentu, yang dikelola oleh urusan kematian yang sesuai dengan golongan si mati. Sejalan dengan pelapisan sosial yang berlaku di daerah ini, maka urusan kematian juga dibedakan menjadi: (1) urusan kematian maramba, (2) urusan kematian kabihu, dan (3) urusan kematian ata. Masing-masing urusan kematian tersebut mempunyai tugas sebagai berikut:

1. Urusan kematian maramba adalah mengatur pelaksanaan penguburan, apabila ada golongan maramba yang meninggal. Kematian seorang maramba, lebih-lebih maramba bokulu (besar) harus diikuti dengan pemotongan binatang, sebanyakbanyaknya. Pemotongan binatang korban dianggap bukan merupakan suatu kerugian, karena mereka percaya bahwa dengan banyak memberi kepada arwah si mati, akan dibalas (oleh arwah si mati) dengan berkatnya yang berlimpah-limpah kepada keluarganya.

Pemakaman jenazah seorang maramba baru dilaksanakan setelah seluruh keluarga yang bertempat tinggal jauh, mulai hadir pada upacara pemakaman, yaitu 7-8 hari setelah meninggal. Untuk menyimpan jenazah pada umumnya dibuat keranda. Selama menunggu pelaksanaan penguburan, jenazah ditunggu oleh orang-orang yang ditunjuk sebagai pengiring. Setiap malam diadakan persembahan kepada arwah dengan memotong ayam, babi dan kerbau.

Setelah upacara pra penguburan atau penguburan sementara selesai, maka dilakukan penguburan yang sebenarnya. Bagi golongan maramba besar, sering dilakukan upacara pemakaman sementara. Dalam pemakaman ini jenazah telah dimakamkan, tetapi belum pemakaman yang sebenarnya, karena sesudah ini 
masih dilakukan pemakaman lagi yang ke duakalinya dengan disertai upacara dan pesta kematian yang terbesar dan terakhir kalinya. Kebiasaan penguburan kedua dilakukan pula oleh beberapa suku bangsa di Indonesia, antara lain: suku bangsa Batak Toba, Toraja, Nias (Soejono, 1977).

Data arkeologi membuktikan bahwa kebiasaan mengadakan penguburan kedua, telah berlangsung sejak masa prasejarah, yaitu masa perundagian. Data tersebut berupa temuan kuburan tempayan di desa Melolo, Kecamatan Rindi Umalulu Sumba Timur tentang kubur tempayan di desa melolo ini telah dibahan dalam sebuah buku yang berjudul "The urn Cemetery at Melolo, East Sumba (Indonesia)" (van Heekeren, 1956). Bukti lain terdapat di situs kuburan Gilimanuk, Bali (Soejono,1977).

2. Urusan kematian kabihu tidaklah seluas dan sebesar urusan golongan maramba. Pengiring jenazah pada kematian kabihu tidak harus dilaksanakan. Jenazah dapat dijaga kaum keluarganya. Binatang yang dipotong cukup empat ekor ayam saja, dan upacara penguburannya pun tidak terlalu lama, yaitu 3-4 hari setelah meninggal.

3. Urusan kematian ata. Dalam golongan ata boluku (besar) upacara penguburan hampir sama dengan golongan kabihu, terutama yang mempunyai kedudukan di dalam golongan maramba. Sedang pada ata kudu (kecil) urusan penguburan lebih sederhana. Binatang korban cukup dipotong seekor, kalau tak ada juga tidak apaapa.

Baik dalam maramba, kabihu mupun ata selama menunggu pelaksanaan penguburan, jenazah dimasukkan ke dalam keranda dengan sikap duduk, lutut terlipat ke atas dan kedua tangan di bawah dagu. Posisi jenazah ini kemudian diikat dengan kain atau ikat kepala. Setelah jenazah diusung dan tiba di tempat penguburan ,kemudian dikeluarkan dan dimasukkan ke dalam lubang kubur dengan posisi seperti dalam kerangda. Sikap mayat yang sedemikian ini di dalam arkeologi dikenal dengan istilah sikap terlipat (flexed position).

Data arkeologi tentang hal ini (flexed position) yaitu temuan rangka dalam sarkofagus di daerah Bali, misalnya di Angantiga, Cacang dan Bisungbiu (Soejono, 1977). Sikap terlipat yang diterapkan pada mayat itu berlaku juga pada suku bangsa Aru, Kei dan Papua, bahkan mayat dengan sikap terlipat ini pada masa prasejarah telah dikenal sejak masa berburu dan pengumpul makanan tingkat lanjut (mesolitik), yaitu dengan temuan rangka manusia di Kyokkenmodinger (Sumatra) dan Gua Sampung di Ponorogo, Jawa Timur (Van Heekeren, 1972) 
Mengenai sikap terlipat ini R.P. Soejono mengemukakan pendapatnya sebagai berikut: sikap terlipat mengandung maksud memberi sikap kepada mayat seakan-akan si mati dalam keadaan siap untuk lair kembali (Soejono, 1977). Pendapat ini apabila dikembalikan kepada kepercayaan marapu, maka kemungkinan besar maksud masyarakat Sumba Timur mengubur mayat dengan sikap terlipat mempunyai tujuan yang sama seperti dikemukakan oleh R.P. Soejono.

Setelah jenazah dimasukkan ke dalam lubang kubur, kemudian dilakukan pemberian bekal kubur oleh keluarga. Bagi golongan maramba, bekal kubur ini terdiri emas, perak, yang berupa perhiasan misalnya manik-manik (mutisalah). Di samping itu bekal kubur dapat berupa senjata, barang-barang anyaman, mata uang, barang tanah liat (periuk), barang keramik dan bahan pakaian. Kain yang digunakan sebagai bekal kubur ditentukan pula oleh kondisi sosial si mati. Selain benda-benda tersebut di atas dikenal pula bekal kubur yang berupa binatang. Bekal kubur yang berupa binatang , sekaligus merupakan. Korban binatang, dapat berupa kerbau, kuda, babi, kambing,
ayam dan anjing.

Adat pemberian bekal kubur pada orang yang meninggal telah berkembang luas sejak masa perundagian, dengan bukti temuan-temuan rangka manusia bersama-sama dengan bekal kuburnya. Adapun benda yang digunakan sebagai bekal kubur juga menunjukkan kesamaan, misalnya perhiasan terdiri dari manik-manik, gelang-gelang perunggu, barang-barang gerabah, senjata baik dari perunggu atau dari besi. Situs kuburan yang demikian ditemukn di Wonosari (Gunungkidul) berupa kubur peti batu, di Plawangan (Rembang) berupa kubur tempayan, dan di Bali dalam kubur sarkofagus
atau keranda batu.

Di samping ditemukan benda yang digunakan sebagai bekal kubur, data arkeologis dapat membuktikan pula bahwa binatang digunakan juga sebagai bekal kubur, yaitu pada situs kubur di Gilimanuk. Temuannya berupa rangka anjing yang ditemukan satu konteks dengan temuan rangka manusia (Soejono, 1977).

Sesudah jenazah dimasukkan dalam lubang kubur beserta bekal kuburnya, kemudian lubang ditutup dengan tanah, kemudian di atasnya diberi lempengan batu yang berbentuk lingkaran atau empat persegi panjang. Untuk golongan maramba, selain ditutup dengan batu bulat, masih pula didirikan sebongkah batu yang berkaki, atau sering disebut dengan nama kubur meja (W.J. Perry. 1918).

Berdasarkan pengamatan secara deskriptif terhadap bentuk kubur di desa Parailiu, Lambanapu dan Kawangu (kecamatan Pandawai), Desa Lewa Paku dan Wundut (kecamatan Lewa), maka bentuk kubur (watu reti). Reti atau yang biasa disebut dolmen, dapat diklasifikasikan menjadi 5 type, yaitu : (1) reti berkaki, (2) reti berdinding, (3) reti bertingkat (berundak), (4) reti tanpa kaki dan (5) reti modern. 
1. Reti berkaki. Reti ini terdiri dari sebongkah batu yang ditopang oleh batu lain, yang berfungsi sebagai kaki. Jumlah kaki bervariasi antara 2 sampai 4 buah atau kadang-kadang lebih banyak lagi. Sedang yang banyak ditemukan adalah yang berkaki 4 . Baik batu yang ditopang maupun kakinya sudah menunjukkan tanda dikerjakan. Jenis reti berkaki ini banyak ditemukan di desa Parailiu, Lambanapu (kecamatan Pandawai) dan desa Paraiyawang (kecamatan Rindi Umalulu). Bentuk kuburan ini dapat dianggap mempunyai bentuk/pola dolmen yaitu salah satu hasil budaya tradisi megalitik.

2. Reti berdinding, bentuk dasar reti ini sama dengan reti tanpa kaki, hanya antara kaki yang satu dengan kaki lainnya ditutup dengan lempengan-lempengan batu, sehingga menyerupai dinding. Pada umumnya lempengan batu lebih tipis bila dibanding dengan batu yang ditopang maupun kakinya, Jenis ini banyak ditemukan di desa Lawapaku (di kecamatan Lewa).

3. Reti bertingkat (berundak), bentuknya seperti reti bertiang, hanya pada bagian batu yang ditopang ditambah batu lain yang lebih kecil. Penutup kubur yang pokok sering pula digunakan sebagai kuburan. Kubur jenis ini ditemukan di Kawangu (kecamatan Pandawai).

4. Reti tanpa kaki, jenis kubur ini hanya terdiri dari sebongkah batu yang digunakan untuk menutup lubang. Reti ini mempunyai bentuk lingkaran, empat persegi panjang atau hanya berupa batu-batu yang disusun melingkar dan melingkari lubang kubur.

5. Selain bentuk tersebut di atas ada pula bentuk kubur (reti) yang mengalami perkembangan, karena prinsipnya tetap sebagai reti berkaki, akan tetapi antara kaki yang satu dengan kaki yang lain diberi dinding bersemen. Reti jenis ini ditemukan di desa Paraiyawang, (kecamatan Rindi Umalulu). Sedang di desa Parailiu (kecamatan Pandawai) terdapat pula reti yang semuanya terbuat dari semen. Bentuk reti ini menyerupai rumah, tetapi tanpa pintu.

Di samping klasifikasi berdasarkan bentuknya, dapat pula dibedakan atas dasar ukurannya, yaitu besar, sedang, dan kecil. Disebut berukuran besar jika panjangnya $200 \mathrm{~cm}$ ke atas atau lebih dari 2 meter. Ukuran sedang, jika panjang berukuran 101$200 \mathrm{~cm}$, disebut berukuran ukuran kecil, jika panjangnya $100 \mathrm{~cm}$ ke bawah.

Pola hias sering dilukiskan pula pada batu penji (sebuah batu yang diletakan di atas tutup, di depan atau di belaknag dan kadang-kadang di samping reti). Selain penji yang dihias, ada pula yang polos sehingga mendekati bentuk menhir. Di kompleks Lewa Paku ditemukan pula penji yang berbentuk patung. Patung ini digambarkan 
tanpa kaki, tangan diletakan di depan perut, sedang mata, mulut dan hidung digambarkan secara sederhana. Bentuk patung jenis ini ditemukan pula didaerah lain, yaitu di Wonosari (Gunungkidul), Bondowoso, dan Bada (Sulawesi tengah). Pada umumnya ditemukan di kompleks kuburan dari tradisi megalitik (Sumiati,1980)

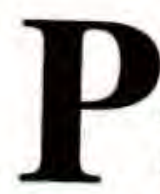

enji dan Kubur Reti di Sumba Timur

Penji sebagai salah satu bentuk tinggalan megalitik yang berupa batu tegak adal (menhir) Penji terpancang dalam kubur reti dalam masyarakat Sumba Timur, peran hal menasik dan perlu dibahas lebih lanjut, baik tentang fungsi maupun peranannya pada masyarakat Sumba Timur.

Secara sederhana penji dapat didefinisikan sebagai batu tegak atau menhir yang khusus terdapat di Sumba Timur. Menhir mempunyai daerah persebaran yang sangat luas di seluruh Indonesia. Sebagai salah satu hasil budaya manusia banyak ditemukan di berbagai situs dan berbagai masa sejak masa bercocok tanam (Hoop, 1938). Bahkan sampai sekarang bentuk tinggalan ini, masih tetap bertahan dan memegang peranan penting, Karena dalam kenyataan sekarang, menhir banyak ditemukan di dalam kuburan baik dalam kuburan Islam maupun Kristen. Di antaranya banyak ditemukan di daerah Sulawesi Selatan, Flores, Nusa Tenggara dan lain-lain (Soejono, 1977).

Dari penelitian arkeologi membuktikan bahwa peninggalan dalam bentuk menhir mempunyai daerah persebaran yang sangat luas di Indonesia. Menhir sebagai salah satu hasil budaya banyak ditemukan di berbagai situs, dan di berbagai masa setelah masa barcocok tanam (Hoop, 1938). Bahkan sampai sekarang bentuk tinggalan ini masih tetap bertahan dan memegang peranan penting, karena dalam kenyataan yang ada sekarang, menhir banyak ditemukan dalam kuburan-kuburan, baik dalam kuburan Islam maupun kuburan Kristen. Diantaranya banyak tersebar di daeah Sulawesi Selatan, Flores, Nusa Tenggara khususunya di Sumba Timur.

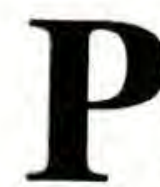

\section{enutup}

Dari uraian di atas dapat ditarik pengertian bahwa di daerah Sumba Timur, sampai sekarang masih berlangsung kepercayaan atau adat-istiadat yang sama dengan tradisi megalitik (prasejarah), khususnya masa perundagian. Panganut adat dan kepercayaan asli hidup berdampingan dengan pemeluk agama Kristen dan Katolik. Penganut kepercayaan asli tetap menjalankan konsep-konsep kepercayaan baik dalam kelahiran, perkawinan maupun kematian. Bahkan seluruh masyarakat Sumba Timur tetap mengakui adanya pelapisan sosial berdasarkan kepercayaan Merapu. 
Status sosial seseorang dapat diketahui dari upacara-upacara yang diadakan pada waktu kematian, di samping dapat pula dilihat dari bentuk kubur kubur atau retinya. Melalui pengamatan secara diskriptif dapat pula dibedakan antara reti yang mempunyai hiasan dan tanpa hiasan. Adapun hiasan yang umum, adalah pola hias binatang, misalnya kerbau, kura-kura, kadal dan ada pula pola hias manusia. Pola hias ini terdapat di bagian depan dan belakang batu yang disangga. Pola hias kerbau kebanyakan hanya dilukiskan bagian kepala lengkap dengan tanduknya, tetapi kadang-kadang cukup tanduknya saja. Pola hias kerbau, kura-kura dan kadal ini ditemukan di desa Paraiyawang (kecamatan Rindiumalulu). Selain pola hias tersebut di atas ada pula pola hias lingkaran, hiasan tumpal, misalnya ditemukan di desa Lambanapu (kecamatan Paraliu).

Pola hias sering dilukiskan pula pada batu penji. Penji adalah sebutan batu tegak (menhir) untuk Sumba Timur. Adapun pola hias pada penji antara lain berupa pedang, kerbau, ayam dan manusia. Golongan maramba, terutama maramba besar, akan memiliki reti yang berukuran besar, mempunyai hiasan dan berbentuk reti berkaki atau berdinding. Di samping itu juga mempunyai penji, yang berhias dengan motif binatang misalnya kerbau, atau pola hias lainnnya melambangkan kekayaannya.

Adanya penji dapat pula melambangkan bahwa yang dikuburkan dalam reti itu adalah panglima perang. Reti bertingkat atau bersusun diperuntukkan bagi golongan maramba besar. Umbu atau rambu dikuburkan ditutup reti, sedang atanya dikuburkan di tanah biasa di bawah tutup.

Golongan kabihu pada umumnya mempunyai reti yang berukuran sedang, berbentuk reti berkaki atau berdinding. Hal yang sama berlaku pula pada golongan ata (hamba) yang mempunyai kedudukan dalam golongan maramba. Bagi golongan ata biasa reti yang dimiliki adalah reti tanpa kaki. Besar kecilnya bentuk kubur melambangkan kebesaran dan kekayaan seseorarng, karena proses pengerjaan dan pemindahannya memerlukan beaya dan tenaga yang besar. Pada umumnya bahan reti diambil dari puncak gunung yang cukup jauh dari lokasi penguburan. Untuk memindahkan batu tersebut diperlukan ribuan tenaga, karena perpindahan batu itu hanya dilakukan oleh tenaga manusia. Dengan demikian hanya golongan yang mempunyai status sosial tinggi, yang dapat membuat reti yang besar dan megah. 
1. Kabihu : istilah kabihu digunakan dalam dua pengertian, yaitu (1) sebagai nama persekutuan hukum kekeluargaan. Di daerah lain dinamakan dengan istilah marga atau suku. (2) sebagai nama golongan derajat keturunan, yakni suatu golongan yang bukan berderajat maramba atau ata.

2. Marapu : dapat berati (1) penghuni langit yang hidup abadi dan dianggap sebagai cikal bakalnya segenap suku yang hidup di Sumba. (2) Arwah nenek moyang di negeri marapu (Parai marapu). Mahluk halus yang menjadi penghuni seluruh penjuru dan ruang alam. Mahluk ini mempunyai kakuatan ghaib yang mempenguruhi kehidupan manusia. 


\section{KEPUSTAKAAN}

Heekeren, H.R. van, 1956. "The Um Cemetery at Melolo, East Sumba (Indonesia)",

Berita Dinas Purbakala, 3, Jakarta. hal 1-5.

1972. "The Stone Age of Indonesia, 2nd rev.ed." Verhandelingen KITLV, LXI. Den Haag, The Hague Martinus Nijhoff.

Heine Geldern, R. Von., 1945. "Prehistoric Research in the Netherlands Indies", Science and Scientists in the Netherlands Indies, Surinam and Curacao.

Hoop, A.N.J. Th.a Th van der, 1932. Megalithic Remains in South-Sumatra, Translated by W. Shirlaw. Zutphen, W.J. Thieme \& Cie

Kapita, Oe.H. 1976. Masyarakat Sumba dan Adat Istiadatnya, Gunung Mulia.

Perry, W.J., I918. The Megalithic Culture of Indonesia. London, (University of Manchester, No.CXVIII, Ethnological Sries, No III).

Soejono, R.P., 1956. On Prehistoric Burial Methods in Indonesia, Jakarta, Bulletin of the Archaeological Institute of Republic of Indonesia

....-.-.-, 1976. Sejarah Nasional Indonesia I, Jakarta, Balai Pustaka.

1977. Sistem-Sistem Penguburan Pada Akhir Masa Prasejarah di Bali, Desertasi, Universitas Indonesia, Jakarta.

Soelarto, B.Tt (tanpa tahun) Pustaka Budaya Sumba, Jakarta Proyek Pengembangan Media Kebudayaan, Ditjenbud, Departemen Pendidikan dan Kebudayaan.

Atmosudiro, S. (I980). Tinjauan Sementara Tentang Arca Menhir Gunung Kidul. Berkala Arkeologi, I(I), 24-4I. https://doi.org/I0.30883/jba.vIiI.274 